\title{
Clinical features and principles of differential diagnosis of erysipelas
}

\author{
S. D. Shapoval, L. A. Vasylevska, V. O. Bielinska
}

Zaporizhzhya Medical Academy of Postgraduation Education

\section{Особливості клінічного перебігу ї принципи диференціальної діагностики бешихи}

\author{
С. Д. Шаповал, Л. А. Василевська, В. О. Белінська \\ Запорізька медична академія післядипломної освіти МОЗ України
}

\begin{abstract}
Objective. The aim is to find out the common and different features of the clinical course of erysipelas from other diseases that can imitate it.

Materials and methods. 114 case histories of patients who were hospitalized in the center of purulent-septic surgery in the City Hospital No 3 in Zaporizhzhia for the period 2019-2020 were analyzed. 123 patients, who underwent hospital treatment in the center during this period of time, were with post-injection abscesses of soft tissue, 184 - with soft tissue abscesses, 203 - with phlegmons of various localizations, 49 - with complicated panaritium, 3 of which - subcutaneous. Over the past 5 years, 127 patients were consulted in the clinic and other therapeutic, infectious, neurological and other departments of the city. A number of criteria and signs have been identified to differentiate erysipelas from diseases that may have similar clinical symptoms and a number of circumstances that need to be clarified.

Results. It is established that the diagnosis of erysipelas does not require special laboratory examination and is made on the basis of examination of the patient, epidemiological history and medical history. Provoking factors in the development of erysipelas are: violation of the integrity of the skin (abrasions, scratches, abrasions, cracks, bruises, injuries); mycoses; a sharp change in temperature (supercooling, overheating); emotional stress; increased insolation. Erysipelas has a characteristic summer-autumn seasonality. In people engaged in physical labor, the disease is registered more often than in other types of work. Hereditary predisposition to the disease is observed in 10-15\% of cases. In this regard, the presence of such factors as congenital and acquired venous insufficiency of the lower extremities, fungal infection of the lower extremities, the presence of postoperative and post-traumatic scars, lymphostasis, diabetes, cardiovascular disease and diseases accompanied by the development of edema, intake of corticosteroids or cytostatics are of essential significance in the development of the disease.

Conclusions. Mathematical modeling between erysipelas and other diseases that have similar syndromes in their clinical picture may be useful in making a differential diagnosis between them.

Ke words: erysipelas; differential diagnosis.

Реферат

Мета. 3'ясувати спільні та відмінні риси клінічного перебігу бешихи й інших захворювань, що можуть ії імітувати.

Матеріали і методи. Проаналізовано 114 історій хвороб пацієнтів, які перебували на стаціонарному лікуванні в Центрі гнійно-септичної хірургії Міської лікарні № 3 м. Запоріжжя у 2019 - 2020 рр. За цей період часу в центрі стаціонарне лікування було проведено 123 хворим з післяін'єкційними абсцесами м'яких тканин, 184 - з абсцесами м'яких тканин, 203 3 флегмонами різних локалізацій, 49 - з ускладненим панарицієм, із них 3 - 3 підшкірним. За 5 попередніх років проконсультовано 127 хворих в поліклініці і терапевтичних, інфекційних, неврологічних та інших відділеннях лікарень міста. Визначено ряд критеріїв та ознак, що дозволяють диференціювати бешиху від захворювань, які у своєму розвитку можуть мати схожу клінічну симптоматику, та ряд обставин, що потребують з’ясування.

Результати. Встановлено, що діагностувати бешиху можливо без спеціального лабораторного обстеження на підставі огляду хворого, даних епідеміологічного анамнезу й анамнезу хвороби. Провокують розвиток бешихи такі фактори: порушення цілісності шкірних покривів (садна, подряпини, тріщини, натерті і забиті місця, травми); мікоз; різка зміна температури тіла (переохолодження, перегрівання); емоційний стрес; підвищена інсоляція. Бешиха має характерну літньо-осінню сезонність. У людей, зайнятих фізичною працею, захворювання реєструється частіше, ніж у людей, які мають інший характер трудової діяльності. Спадкова схильність до захворювання відзначається у 10 - 15\% пацієнтів. У зв'язку з цим у разі розвитку хвороби істотне значення має наявність таких факторів, як вроджена і придбана венозна недостатність, грибкова інфекція нижніх кінцівок, наявність післяопераційних і післятравматичних рубців, лімфостаз, цукровий діабет, серцево-судинні захворювання, а також захворювання, що супроводжуються розвитком набряків, потребують прийому кортикостероїдів, цитостатиків.

Висновки. Математичне моделювання між бешихою та іншими захворюваннями, які мають у своїй клінічній картині подібні синдроми, може бути корисним при проведенні диференціальної діагностики між ними.

ключові слова: бешиха; диференціальна діагностика.
\end{abstract}

In modern conditions, the problem of erysipelas remains highly relevant in the health care system. In recent years, the incidence of infections caused by -hemolytic streptococcus group A has increased significantly. According to current data, the average incidence of erysipelas in Europe is 4.3 per
10,000 adults $[1,2]$, with increasing number of young and middle-aged patients. More than $60 \%$ of patients with erysipelas are 40 years and older, mostly women [3, 4].

Recently, infectious-allergic manifestations of the disease, as well as the number of complicated forms of erysipelas 
and its recurrence have increased [ $5-7]$. Changes in clinical symptoms and the course of the disease with the development of severe complications and sepsis became more frequent. In the structure of patients with purulent-necrotic diseases, which require surgery, the patients with complicated forms of erysipelas make up $6.7-21 \%$. Mortality in the necrotic form of erysipelas ranges from 5.8 to $81 \%[8,9]$.

The relevance of early diagnosis of erysipelas was determined by peculiarities of the epidemiology and clinical course of the disease. Erysipelas should be differentiated from dozens of diseases, which in clinical manifestations are surgical, infectious, cutaneous and internal. First of all, it is necessary to exclude surgical pathology. Given the general mechanisms of pathogenesis of erysipelas and the main pathological changes of soft tissues, related to the competence of surgery, namely the main tissue response to trauma and / or the development of an inflammatory reaction, the symptoms of these diseases have much in common $[10-13]$.

The purpose of the study: to determine the common and distinctive features of the clinical course of erysipelas and other diseases that can mimic it.

\section{Materials and methods}

There were 114 patients with erysipelas, who were hospitalized at the Center for Purulent-Septic Surgery of the City Hospital №3 in Zaporizhia in 2019 - 2020, and included in this study.

All the patients were diagnosed with erysipelas. According to the forms of erysipelas, the distribution of patients was as follows: erythematous - 24 (21.0\%), bullous - 28 (24.6\%), phlegmonous - 48 (42.1\%), and necrotic - 14 (12.3\%). Recurrence of the disease was observed in 21 patients: in erythematous form - in 4 (16.7\%), bullous - in 5 (17.9\%), phlegmonous - in 9 (18.7\%), and necrotic - in 3 (21.4\%).

During this period, 123 patients with the post-injection soft tissue abscesses, 184 - with soft tissue abscesses, 203 with phlegmons of various localizations, 49 - with complicated panaritium, of which -3 - with subcutaneous . Over the past 5 years, 127 patients were consulted in the clinical and therapeutic, infectious, neurological and other departments of hospitals in the city.

A number of criteria and signs have been identified to differentiate erysipelas from diseases, which may have similar clinical symptoms in their development, and a number of circumstances that need to be clarified, namely: epidemiological history; characteristics of the onset of the disease: acute with high fever, with symptoms of severe intoxication, without intoxication; languid; lingering; characteristics of the pain syndrome: pain at rest, pain when moving, expansive, throbbing, limited; palpation data: severe pain, only in the center of the infiltrate, outside the infiltrate, the presence of fluctuations; hyperemia: without clear boundaries, very common, in the form of spots or stripes, with bubbles, symmetrical; erythema color: crimson-red, pink, bright pink, with a purple tinge, bluish, purple; the phenom- enon of lymphangitis; regional lymphadenopathy; "Crunch" in the tissues.

\section{Results}

The possibility to diagnose erysipelas without a special laboratory data, on the basis of examination of the patient, data of epidemiological anamnesis and anamnesis of the disease, were established.

The development of erysipelas is provoked by following factors: violation of the skin integrity (abrasions, scratches, cracks, abrasions and bruises, injuries); mycosis; a sharp change in the body temperature (hypothermia, overheating); emotional stress; increased insolation.

Erysipelas has a characteristic summer-autumn seasonality. In people, engaged in physical work, the disease is registered more often than in others. Hereditary predisposition to the disease is observed in $10-15 \%$ of patients.

In this regard, in the case of the disease, the presence of such factors as congenital and acquired venous insufficiency, fungal infection of the lower extremities, the presence of postoperative and post-traumatic scars, lymphostasis, diabetes, cardiovascular disease, and the diseases with accompanied edema, require corticosteroids, cytostatics is registered.

In the clinical course of erysipelas two periods are distinguished - the beginning and the height of the disease.

The initial period of the disease is characterized by rapid development of the intoxication symptoms, which appear from several hours to 1-2 days ahead of local manifestations in more than half of the patients (usually with localization of the process in the lower extremities). Headache, fever, general weakness, muscle pain, loss of appetite are noted, $25-30 \%$ of the patients experience nausea and vomiting. Already in the first hours of the disease the body temperature rises up to $38-40{ }^{\circ} \mathrm{C}$. In the skin areas of future local manifestations, a number of patients complain for feeling of paresthesia, distension or burning, mild pain. There are often unpleasant sensations in the area of enlarged regional lymph nodes also.

The onset of the disease occurs in a few hours to $1-2$ days after its first manifestations. During this period, general toxic manifestations and fever reach their maximum. There are characteristic local signs of erysipelas. Most often the inflammatory process is localized on the lower extremities $(60-70 \%)$, less often - on the face $(20-30 \%)$ and upper extremities $(4-7 \%)$, very rarely - on the torso, breast, perineum, external genitalia.

Erysipelas should be differentiated from dozens of diseases, related to surgery, infectious diseases, dermatology and internal medicine. First of all, it is necessary to exclude surgical pathology.

The main differences that allow to differentiate between surgical diseases and erysipelas are associated with deeper soft tissue lesions in surgical pathology and, as a rule, isolated lesions of the skin and its appendages in erysipelas (Table 1).

Abscesses in the infiltration stage are most often perceived as erysipelas. In the area of abscess formation, there 
is a dense infiltration and swelling not only of the skin but also of soft tissues, An area of skin hyperemia over the infiltrate without clear boundaries and significant spread is noted as well. During palpation a pain in the infiltrate center is defined. Later (during abscessing) there is fluctuation. Pain in the site of inflammation has an expansive, throbbing nature, it is observed at rest and is especially exacerbated by movements in the affected limb. The abscesses often develop at the injection site.

The clinical course of phlegmon begins acutely, with fever and the phenomena of the acute intoxication. However, as with an abscess, in contrast to erysipelas, at the site of localization of the process there is severe pain, sometimes throbbing, and there is a sharp pain during palpation. Hyperemia of the skin does not have clear contours, develops at the background of a pronounced dense infiltration of subcutaneous tissue and deeper tissues. Later, the infiltrate softens and fluctuates. Subcutaneous phlegmon may be accompanied by lymphangitis.

Given the post-traumatic nature of hematomas, the disease history is of particular importance. It is also important to assess the time intervals: the development of inflammation in erysipelas begins with fever and suppuration of hematoma, leading to hyperthermia, rarely occurring less than in $3-5-7$ days.

Cellulitis is a diffuse acute inflammation of the skin and subcutaneous tissue, characterized by hardening, redness, swelling of tissues without cell necrosis or suppuration, often accompanied by pain and fever, lymphangitis and regional lymphadenopathy. Recurrent cellulitis is often associated with disorders of the venous and lymphatic systems. As a rule, traumatic or surgical interventions in the lymphatic system cause the first manifestations of cellulitis. Hypostatic processes, as well as mycosis of the feet, contribute to the appearance of cellulitis of the lower extremities, as the barrier function of the skin is disturbed and the pyococcal flora penetrates through the skin, damaged by mycosis, more easily. Often cellulitis develops after venectomy of the great saphenous vein. The clinical picture of cellulitis is characterized by diffuse erythema, dense, hot and painful on palpation, the edges of which are blurred, while the sizes can be different: small (localized) - cellulitis of the finger and large, when the process captures the whole shoulder or buttocks - post-injection cellulitis. Areas of the lesion are increasing rapidly in size, become a plaque-like, swollen, accompanied by fever. Bubbles may be formed on their surface. Cellulitis around the ulcers develops more slowly and less acutely, usually without fever.

Erysipelas differs from cellulitis by involvement in the process of the lymphatic tissue, in which the pathogen multiplies, as well as a more superficial nature of the process and a clearer demarcation of the marginal area from the unaffected surrounding skin.

Bacterial damage to the superficial and deep fascia (connective tissue of the muscles, blood vessels and internal organs) of the lower extremities, as well as subcutaneous tissue, may cause necrotizing fasciitis. The activity of pathogenic microorganisms leads to the development of necrosis (gangrene). In the initial stages, the only symptom of necrotizing fasciitis is pain at the site of the necrotic process, which is exacerbated by pressure. Later there is swelling, which rapidly increases in size. The skin on its surface turns red and becomes hot. In addition, blisters with serous-hemorrhagic contents may appear on the skin surface. As the disease progresses, the skin becomes bluish and sometimes purple. In addition, there is a very characteristic "crunch" in the tissues, which is associated with reproduction of anaerobic bacteria. The activity of microorganisms leads to formation of the gas bubbles in tissues, which burst with a characteristic sound. Severe intoxication may cause confusion.

In the case of slow course, whitlow is accompanied by redness of the skin of one finger, intense dilating and (or) throbbing pain at rest. However, the pain is significantly increased if you press on the inflamed phalanx, there is a restriction of movement in the distal and proximal interphalangeal joints. Skin hyperemia does not extend from the finger to the hand and forearm and is clearly limited, with fluctuations in the center of inflammation. The patient has no intoxication.

Erysipeloid (swine erysipelas) is a skin form of the disease. The disease refers to zoonoses with a short incubation period ( $2-3$ days). Epidemiological history (microtrauma of the skin during meat or fish processing, staying in natural foci of erysipeloid) is of great importance for diagnosis. The disease begins with the appearance of erythema on the skin of the fingers and hands (more than 90\% of patients), while in erysipelas such localization of the process is casuistically rare. Itching, slightly painful erythema from pink to crimson-red color with a paler center, covering the fingers and sometimes passing to the hands, develop in the area of the entrance gate. The edges of the erythema are brighter than the center, the swelling is more pronounced on the periphery. The affected area is not hot to the touch. On the background of erythema the individual vesicular elements with serous or hemorrhagic content appear sometimes. Characteristic is the absence of fever, intoxication and regional lymphadenitis.

Thrombophlebitis (phlebitis) of the subcutaneous veins is accompanied by pain along the vessels of the affected limb, its edema. If the process develops in the lower extremities, then, as a rule, in the anamnesis there are often varicose veins. The development of phlebitis in the upper extremities is usually preceded by a history of intravenous injections or infusions. Hyperemia of the skin is observed in the form of spots or streaks over the affected veins, while the swelling captures the entire limb and does not coincide with the contours of hyperemia. At a palpation along the veins consolidations in the form of nodules are noted, veins are dense and painful. There is no regional lymphadenitis. Thus, the main difference between phlebitis and erysipelas is the local signs of an inflammatory reaction along the main trunks of superficial veins or their tributaries. 


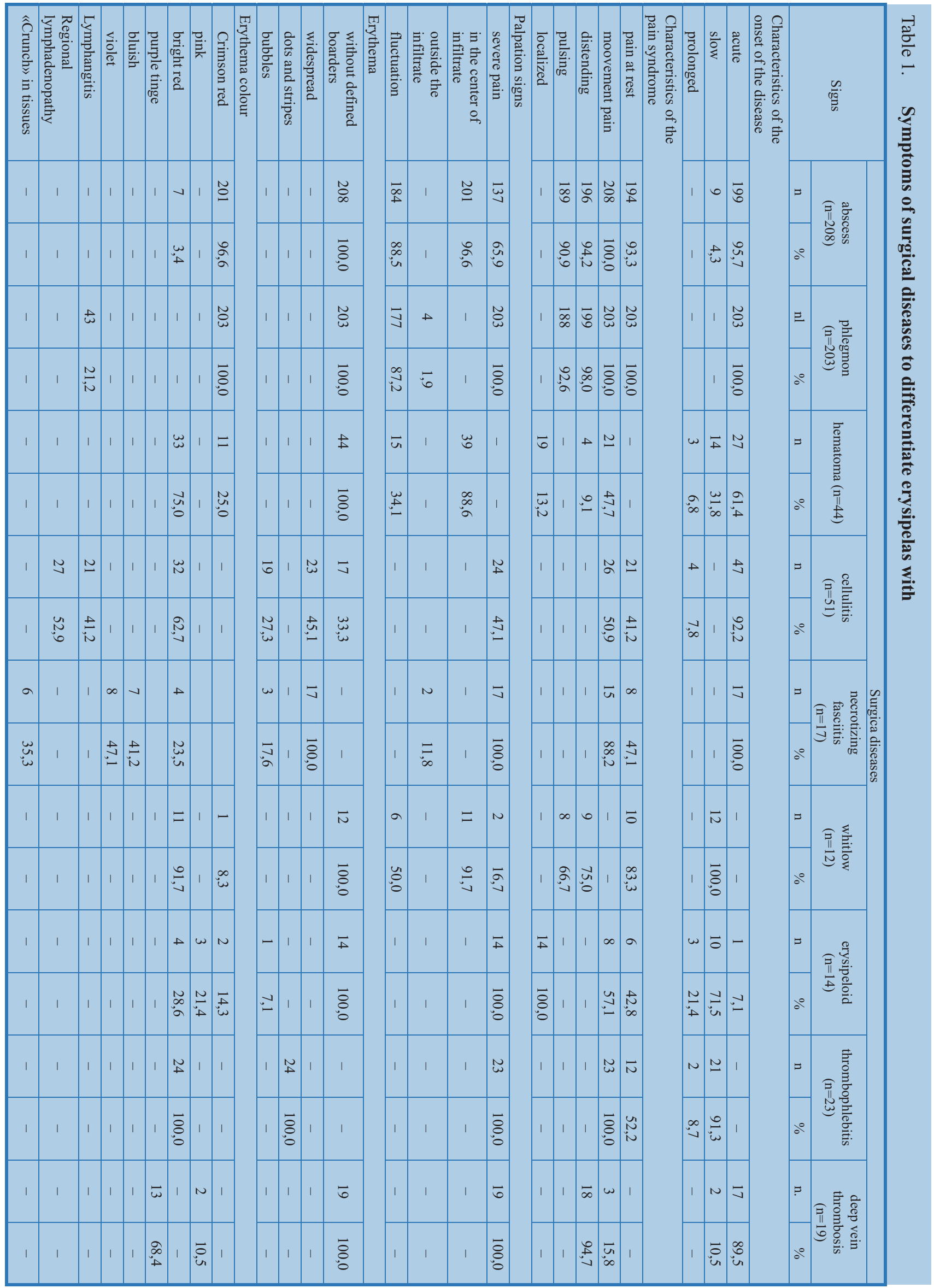


The deep vein thrombosis occurs acutely and is manifested by pain, edema, cyanosis of the extremities. Body temperature is often subfebrile, and, in contrast to erysipelas, redness is rare. However, local changes in deep vein thrombosis, namely, hyperemia and edema, are not accompanied by clear boundaries and are more dense. Hyperemia is less pronounced with a crimson or purple hue. The pain is dull, expansive, localized in the muscles, the characteristic symptoms (Homans and Moses) are determined. The main differential diagnostic method is ultrasound angioscanning of deep veins.

No less important is the differential diagnosis of erysipelas and many non-surgical diseases (Table 2).

Shingles begins with pain along the nerve trunks, what determines the size of the skin area affected. On the background of the skin erythema areas there are numerous blisters, filled with serous, hemorrhagic, sometimes purulent, contents. Yellow-brown or black crusts gradually form in the place of bubbles; the disease often acquires a prolonged course, accompanied by severe neuralgia.

Erythema nodosum is a deep allergic vasculitis, polyetiological disease, in the occurrence of which streptococcal infection plays a role. As with erysipelas, erythema nodosum is often preceded by sore throat or a history of patients with an indication for chronic tonsillitis. The disease begins acutely, with fever, symptoms of intoxication. In the legs area, less often on the thighs and forearms, and occasionally symmetrically on the abdomen, a several large, dense, painful nodes, which rise slightly above the surface of the skin, are poured. The boundaries of the nodes are vaguely defined. The skin over the nodes is bright pink, then becomes cyanotic. At the beginning of nodular erythema, a pain in the extremities, knees and ankles is possible. Despite the similar initial period of the disease with erysipelas, the formation of several limited nodes with local reddening of the skin over them does not fit into the picture of the local process in erysipelas, what allows to exclude this diagnosis.

Phlebotoderma occurs after the insect bites (wasps, hornets, bees) in people with hypersensitivity. The onset of the disease is indicated by signs of intoxication (fever, vomiting). At the site of the bite there is significant swelling, moderate redness of the skin without a clear boundary. Diagnosis is facilitated by the association of the condition with an insect bite, the presence in the center of a bite mark in the form of a dot, sometimes an insect sting, as well as a moderate pain and itching.

Lyme disease in $80 \%$ of patients manifests as migrating erythema from 1 to $70 \mathrm{~cm}$ in diameter, with an elevated contour, often has an area of enlightenment in the center, where a trace of a tick bite can be seen. The diagnosis of Lyme disease takes into account the presence of people (visiting forests, parks) in endemic areas, taking into account the season, the fact of tick infestation, the development of disease with signs of infectious process after tick infestation, clinical signs such as migrating erythema, chronic atrophic acrodermatitis, radiculoneuritis.
Hemorrhagic vasculitis of a skin type constitutes $70 \%$ of all types. For unknown reasons, on the inner surface of the walls of blood vessels the deposition of immune complexes occurs, which contributes to inflammation of microvessels of the skin and internal organs. Hemorrhages rise above the skin, may merge and form irregularly shaped bubbles with hemorrhagic contents. Most often they are localized on the feet and hands, thighs and buttocks, abdomen, face and joints. After a while the hemorrhages disappear, but dark areas remain in their place. In severe hemorrhagic vasculitis, areas of the skin prone to rash may become inflamed, and the skin necrosis may occur. The patient complains of pain in the joints and abdomen, the impaired kidney and intestinal function, possible bleeding and renal failure.

\section{Discussion}

Erysipelas and abscess have a lot in common, but there are some signs that can distinguish these diseases. In $4.3 \%$ of patients with abscesses there was a slow onset of the disease, which was not the case with erysipelas. Pain at rest was by $5.8 \%$ more common in patients with erysipelas, what have appeared statistically significant $(\mathrm{F}=0.0234 ; \mathrm{p}<0.05)$, while $90.9 \%$ of patients with abscesses complained of throbbing pain. This sign was not observed in erysipelas.

Severe pain in the affected area on palpation was statistically significantly (32.3\%) more often caused by erysipelas ( $\mathrm{F}<0.0001 ; \mathrm{p}<0.0001)$. The symptom of fluctuation, on the contrary, was by $41.1 \%$ more often observed in abscesses $\left(\chi^{2}=64.49 ; \mathrm{p}<0.0001\right)$. Also in abscesses there was pain in the infiltrate center only (96.6\%), what is not typical for erysipelas.

Erysipelas can be distinguished from an abscess by more widespread hyperemia with clear borders, and at $32,5 \%$ of patients $=$ with bubbles. Erythema is similar in color, but $4.4 \%$ of patients with erysipelas had bluish erythema, which is not typical to an abscess.

Erysipelas and phlegmon are similar in many respects, but there are clear differences that allow to differentiate the two diseases. Almost all patients with phlegmon (92.6\%) have complained of throbbing pain, which is not characteristic for erysipelas, while. $1.9 \%$ of patients with phlegmon had pain outside the affected area, what was not the case with patients, suffering erysipelas. The symptom of fluctuation was statistically significantly in 2 times more common in phlegmon than in erysipelas $\left(\chi^{2}=58.56\right.$; $\left.\mathrm{p}<0.0001\right)$.

Hyperemia in phlegmon have had no clear boundaries. In erysipelas, hyperemia had clear boundaries, was significantly widespread, and $32.5 \%$ of the patients owed blisters. In all patients with phlegmon, the color of erythema was crimson-red, and in erysipelas in $1.7 \%$ of patients - bright red, and in $4.4 \%$ of patients - bluish.

Erysipelas and hematoma after injury have some common features and many differences. With hematoma, the acute onset of the disease was observed in only $61.4 \%$ of patients. Slow (31.8\%) or prolonged (6.8\%) course have distinguished hematoma from erysipelas. Hematoma is not 
Table 2. Symptoms of non-surgical diseases to differentiate erysipelas with

\begin{tabular}{|c|c|c|c|c|c|c|c|c|c|c|}
\hline \multirow{3}{*}{ Signs } & \multicolumn{10}{|c|}{ Non-surgica diseases } \\
\hline & \multicolumn{2}{|c|}{$\begin{array}{c}\text { shingles } \\
(\mathrm{n}=12)\end{array}$} & \multicolumn{2}{|c|}{$\begin{array}{l}\text { erythema nodosum } \\
\qquad(\mathrm{n}=14)\end{array}$} & \multicolumn{2}{|c|}{$\begin{array}{l}\text { phlebotoderma } \\
\quad(\mathrm{n}=11)\end{array}$} & \multicolumn{2}{|c|}{$\begin{array}{l}\text { lyme disease } \\
\quad(\mathrm{n}=9)\end{array}$} & \multicolumn{2}{|c|}{$\begin{array}{l}\text { hemorrhagic vasculitis } \\
\qquad \begin{array}{l}\text { (skin type) } \\
(\mathrm{n}=13)\end{array}\end{array}$} \\
\hline & $\mathrm{n}$ & $\%$ & $\mathrm{n}$ & $\%$ & $\mathrm{n}$ & $\%$ & $\mathrm{n}$ & $\%$ & $\mathrm{n}$ & $\%$ \\
\hline \multicolumn{11}{|c|}{$\begin{array}{l}\text { Characteristics of the onset of } t \\
\text { disease }\end{array}$} \\
\hline acute & 4 & 33,3 & 14 & 100,0 & 11 & 100,0 & 9 & 100,0 & 11 & 84,6 \\
\hline slow & 9 & 75,0 & - & - & - & - & - & - & 2 & 15,4 \\
\hline prolonged & 2 & 16,7 & - & - & - & - & - & - & - & - \\
\hline \multicolumn{11}{|l|}{$\begin{array}{l}\text { Characteristics of the pain } \\
\text { syndrome }\end{array}$} \\
\hline pain at rest & 10 & 83,3 & 14 & 100,0 & 11 & 100,0 & 9 & 100,0 & 13 & 100,0 \\
\hline moovement pain & - & - & 14 & 100,0 & - & - & - & - & - & - \\
\hline distending & 4 & 33,3 & - & - & - & - & - & - & - & - \\
\hline pulsing & - & - & - & - & - & - & - & - & - & - \\
\hline localized & 1 & 8,3 & - & - & 9 & 81,8 & - & - & - & - \\
\hline \multicolumn{11}{|l|}{ Palpation signs } \\
\hline severe pain & 12 & 100,0 & - & - & - & - & - & - & 13 & 100,0 \\
\hline in the center of infiltrate & - & - & 14 & 100,0 & 9 & 81,8 & 9 & 100,0 & - & - \\
\hline outside the infiltrate & - & - & - & - & - & - & - & - & - & - \\
\hline fluctuation & - & - & - & - & - & - & - & - & - & - \\
\hline \multicolumn{11}{|l|}{ Erythema } \\
\hline without defined boarders & 9 & 75,0 & 14 & 100,0 & 11 & 100,0 & 9 & 100,0 & 11 & 84,6 \\
\hline widespread & - & - & - & - & - & - & - & - & - & - \\
\hline dots and stripes & - & - & - & - & - & - & - & - & - & - \\
\hline bubbles & 7 & 55,3 & - & - & - & - & - & - & 3 & 23,1 \\
\hline erythema colour & - & - & 12 & 85,7 & - & - & - & - & - & - \\
\hline \multicolumn{11}{|l|}{ Crimson red } \\
\hline pink & - & - & - & - & - & - & - & - & - & - \\
\hline bright red & - & - & - & - & - & - & - & - & - & - \\
\hline purple tinge & 12 & 100,0 & 14 & 100,0 & 11 & 100,0 & 9 & 100,0 & - & - \\
\hline bluish & - & - & - & - & - & - & - & - & - & - \\
\hline violet & - & - & 3 & 21,4 & - & - & - & - & 7 & 63,6 \\
\hline in the center of infiltrate & - & - & - & - & - & - & - & - & - & - \\
\hline Lymphangitis & - & - & - & - & - & - & - & - & - & - \\
\hline Regional lymphadenopathy & - & - & - & - & - & - & - & - & - & - \\
\hline «Crunch» in tissues & - & - & - & - & - & - & - & - & - & - \\
\hline
\end{tabular}

characterized by pain at rest, which was found in $99.1 \%$ of the patients, suffering erysipelas. The pain while movement was statistically significantly more common in erysipelas ( $\mathrm{F}$ $<0.0001$; $<<0.0001$ ), while $9.1 \%$ of patients with hematoma and $98.2 \%$ of patients with erysipelas have complained of stabbing pain, the difference was statistically significant ( $\mathrm{F}<0.0001 ; \mathrm{p}<0.0001)$. In $13.2 \%$ of patients with hemato$\mathrm{ma}$, the pain was limited, what is not typical for erysipelas.

In $98.2 \%$ of patients with erysipelas there was a severe pain in the affected area, what was not the case with hematoma. However, $88.6 \%$ of patients with hematoma complained of pain in the infiltrate center only, what is not typical for erysipelas. Erysipelas can be distinguished from hematoma by typical hyperemia with clear boundaries and a significant spread, and in $32.5 \%$ of patients, having the blisters. In all patients with hematoma, hyperemia had no clear boundaries.
In erysipelas, the crimson-red color of erythema have been predominated $\left(\chi^{2}=76.02 ; \mathrm{p}<0.0001\right)$. Erythema of bright red color was statistically significantly more often observed in patients with hematoma $(\mathrm{F}<0.0001$; $\mathrm{p}<0.0001)$.

Common symptoms for erysipelas and cellulitis were: acute onset of the disease, pain at rest and during movement, severe pain on palpation, widespread redness, sometimes with blisters, bright red erythema. For the differential diagnosis of these diseases, it is important, that $7.8 \%$ of patients with cellulitis had a prolonged course of the disease, what was never observed in erysipelas.

In cellulitis, in contrast to erysipelas, there were in 2 times fewer patients with complaints for pain at rest ( $\mathrm{F}<0.0001$; $\mathrm{p}$ $<0.0001)$ and with movements ( $\mathrm{F}<0.0001$; $\mathrm{p}<0.0001)$. Expansive pain in cellulitis was not observed, what have also distinguished this disease from erysipelas. 
The expressed pain in the affected area on palpation was statistically significantly more common in erysipelas $(\mathrm{F}<0.0001 ; \mathrm{p}<0.0001)$. In addition, half of the patients with erysipelas have shown the signs of fluctuation, which were not characteristic for cellulitis.

In one third of patients with cellulitis, hyperemia had no clear boundaries, while in all patients with erysipelas, on the contrary, hyperemia was clearly limited. Common hyperemia was observed in only half of patients with cellulitis, what is statistically significantly less than in erysipelas ( $\mathrm{F}$ $<0.0001$; $\mathrm{p}<0.0001$ ).

Only $1.7 \%$ of patients with erysipelas had a bright red color of erythema, while in cellulitis more than half of patients (62.7\%) showed this feature, the difference is statistically significant $\left(\chi^{2}=108.31 ; \mathrm{p}<0.0001\right)$. Erythema of crimson-red and bluish color, typical of erysipelas, was not observed in cellulitis at all. Cellulitis was accompanied by the phenomena of lymphangitis (41.2\% of patients) and regional lymphadenitis (52.9\%), which were not detected in erysipelas.

Pain at rest have occurred statistically significantly more often (in 2 times) in the patients, suffering erysipelas ( $F$ $<0.0001 ; \mathrm{p}<0.0001$ ), compared to those with necrotizing fasciitis. Almost all patients with erysipelas (98.2\%) have complained of stabbing pain, while in those with necrotizing fasciitis such a complaints was absent at all.

Palpation in $11.8 \%$ of patients with necrotizing fasciitis have revealed the pain outside infiltrate, what is not typical for erysipelas. In a statistically significantly larger number of patients with necrotizing fasciitis, the erythema was bright red $(\mathrm{F}=0.0156 ; \mathrm{p}<0.05)$ and bluish $\left(\chi^{2}=14.58 ; \mathrm{p}=\right.$ 0.0001 ). A crimson-red erythema (93.9\%) was observed in most patients with erysipelas, what is not typical for those, suffering fasciitis. In $47.1 \%$ of patients with necrotizing fasciitis a violet erythema was noted, while in erysipelas it was absent. In both diseases, there was a "crunch" in the tissues, but it was more characteristic for necrotizing fasciitis - in $35.3 \%$ of patients $\left(\chi^{2}=6.49 ; \mathrm{p}=0.0108\right)$.

A whitlow, in contrast to the disease of erysipelas, have begun slowly. A pain at rest was statistically significantly more typical for erysipelas ( $\mathrm{F}=0.0238 ; \mathrm{p}<0.05)$, as well as a stabbing pain symptom $(\mathrm{F}=0.0060 ; \mathrm{p}<0.05)$. Erysipelas have differed from whitlow by the presence of pain in movements in $98.2 \%$ of patients and the absence of a throbbing pain.

A severe pain while palpation was observed in $98.2 \%$ of patients with erysipelas and in $16.7 \%$ - with a whitlow (F $<0.0001 ; \mathrm{p}<0.0001$ ), while $91.7 \%$ of patients with a whitlow have shown a pain in the infiltrate center only, what distinguished this pathology from erysipelas also. Hyperemia in whitlow had no clear boundaries and was not significantly common, while in erysipelas hyperemia was significantly common, with clear boundaries, and in every one third of the patients - with bubbles.

A crimson-red color of erythema was more typical for erysipelas, while for panaritium - bright red, the difference is statistically significant $(\mathrm{F}<0.0001 ; \mathrm{p}<0.0001)$. In addition, in erysipelas in $4.4 \%$ of patients the erythema was generally bluish.
There were some common features in erysipelas and erysipeloid. However, there are many differences between these diseases, what can be used to make a differential diagnosis. If erysipelas have begun in all the patients acutely, erysipeloid - in $7.1 \%$ only, while in other patients the disease began slowly (91.3\%).

The pain in rest and movement was common in both diseases, but statistically significantly more common - in erysipelas ( $\mathrm{F}<0.0001 ; \mathrm{p}<0.0001)$. In all patients with erysipeloid, the pain was limited and not characterized as distending, which distinguished them from patients with erysipelas.

In erysipeloid hyperemia was not common and had no clear boundaries. Erysipelas was characterized by widespread hyperemia with clear boundaries. Bubbles were observed more often in patients with erysipelas $-32.5 \%$ than in patients with erysipeloid $-7.1 \%$, but there was no statistically significant difference in this feature between patients ( $\mathrm{F}$ $=0.0635 ; \mathrm{p}>0.05)$.

Crimson-red erythema was statistically significantly more common in erysipelas ( $\mathrm{F}<0.0001 ; \mathrm{p}<0.0001)$. Bright red, in contrast, was statistically significantly more likely to indicate the presence of erysipeloid $(\mathrm{F}=0.0012 ; \mathrm{p}<0.05)$. Pink erythema was found in $21.4 \%$ of patients with erysipeloid, which was not typical for erysipelas.

Erysipelas and thrombophlebitis did not have many common symptoms, but some patients also needed a differential diagnosis.

Erysipelas always had an acute onset, and in thrombophlebitis in most patients (91.3\%) there was a slow course of the disease, sometimes even prolonged (8.7\%). Pain at rest was statistically significantly more common in erysipelas (F $<0.0001 ; \mathrm{p}<0.0001)$. Almost all the patients with erysipelas (98.2\%) have complained of stabbing pain, which was not detected in thrombophlebitis.

Palpation in $47.4 \%$ of patients with erysipelas nave shown a positive symptom of fluctuation, not typical for thrombophlebitis. Hyperemia in the form of spots or stripes was observed in patients with thrombophlebitis, what distinguished them from the patients with erysipelas. All patients with thrombophlebitis had bright red erythema. With erysipelas, such erythema was observed in only $1.7 \%$ of patients.

Differential diagnosis of erysipelas and deep vein thrombosis was based on the following features. In most patients with thrombosis (89.5\%), as in patients with erysipelas, the disease have begun acutely, but in $10.5 \%$ of patients with thrombosis the disease began slow, which was not characteristic for erythema. The pain during movements was statistically significantly more often (6 times) observed in patients with erysipelas ( $\mathrm{F}<0.0001 ; \mathrm{p}<0.0001$ ), and $99.1 \%$ of patients with erysipelas complained of pain at rest, what is not typical for thrombosis. A positive symptom of fluctuation was found in $47.4 \%$ of patients with erysipelas.

Hyperemia in thrombosis had no clear boundaries, erythema was pink (10.5\%) or with a purple tinge (68.4\%), what immediately gave reason to exclude a patient with erysipelas, which was characterized by significant hyperemia (99.1\%) 
with blisters (32.5\%) and crimson-red (93.9\%), and sometimes bright red (1.7\%) or bluish (4.4\%), color of erythema.

\section{Conclusions}

1. Criteria for the diagnosis of erysipelas are an acute onset of the disease with fever, rapid rise in body temperature, the development of intoxication syndrome; early appearance of local sensations (pain, itching, burning) with further development of local inflammatory changes; typical characteristics of erythema (bright, with clear uneven borders, edge roller); the presence of regional lymphadenitis; selective localization of the process (shins, face); recurrent erythema: the presence of the consequences of erythema (lymphostasis), not severe intoxication syndrome and smoothed local status; the presence of comorbidities, contributing to the development of erysipelas; unfavorable professional working conditions; erysipelas in anamnesis, taking into account how long ago, location, severity and number of times.

2. Mathematical modeling between erysipelas and other diseases, which have similar syndromes in their clinical picture, may be useful in making a differential diagnosis between them.

Financing. This study is a fragment of the research work of the Institute of Sepsis of the State Institution "ZMAPO of the Ministry of Health of Ukraine" "Sepsis in patients with surgical forms of erysipelas".

Contribution of autbors. The contribution of all authors to this work is the same. All authors have read and approved the final version of the manuscript.

Conflict of interest. The authors who participated in this study stated that they had no conflict of interest regarding this manuscript.

Consent to publication. All authors have agreed to publish this manuscript.

\section{References}

1. Lisko OB, Satarova SA, Perminova TA, Gavrilova IB. Erysipelas a social-medical problem at the present stage. In: IX Annual Russian Congress on infectious diseases with international participation. Moscow. 2017; 155. Russian.

2. Massone C, Fink-Puches R, Cerroni L. Atypical clinical presentation of primary and secondary cutaneous follicle center lymphoma (FCL) on the head characterized by macular lesions. J Am Acad Dermatol. 2016 Nov;75(5):1000-1006. doi: 10.1016/j.jaad.2016.05.039. Epub 2016 Jul 2. PMID: 27380773.
3. Blagney LP, Avdeeva MG, Kovalevskaya OI, Kozyrev EV. Peculiarities of erysipelas in different age groups. In: IX Annual Russian Congress on infectious diseases with international participation. Moscow. 2017; 43. Russian.

4. Moskovaya T, Pshenichnaya N, Kucherenko I. Pathogenetic significance of macrophage inflammatory protein-IA in patients with erysipelas of the lower extremities. International Journal of Infectious Diseases. 2016;45(Suppl. 1):146. doi: 10.1016/j.ijid.2016.02.355.

5. Ratnikova LI, Ship SA, Dubovikova TA, Barsukova DN. Erysipelas: modern features and new possibilities of pathogenetic therapy. Yuzhno-uralskiy medicinsky zhurnal. 2016;(2):12-7. Russian.

6. Erovichenkov AA, Domonova EA, Potekaeva SA, Svistunova TS, Matosova SV, Shipulina OYu, et al. Modern molecular methods in the study of etiology of bullous hemorrhagic form of erysipelas of lower extremities. Infectious Diseases. 2016;(2):6-12. doi: 10.20953/1729-9225-2016-2-6-12. Russian.

7. Yang SS, Chandran NS, Huang JX, Tan KB, Aw DC. A Fatal Case of "Bullous Erysipelas-like" Pseudomonas Vasculitis. Indian J Dermatol. 2016 Jan-Feb;61(1):120. doi: 10.4103/0019-5154.174095. PMID: 26955132; PMCID: PMC4763643.

8. Brazhnik EA, Ostroushko AP. Erysipelas in a surgical practice. Scientific review. Medical sciences. 2016;(4):14-7. Russian.

9. Krasagakis K, Valachis A, Maniatakis P, Krüger-Krasagakis S, Samonis G, Tosca AD. Analysis of epidemiology, clinical features and management of erysipelas. Int J Dermatol. 2010 Sep;49(9):1012-7. doi: 10.1111/j.1365-4632.2010.04464.x. PMID: 20931671.

10. Plavunov NF, Kadyshev VA, Chernobrovkina TY, Proskurina LN, Kardonova EV. Diagnostic signification of exanthema in the prehospital care in infectious diseases. Russian Archives of Internal Medicine. 2016;6(3):36-41. Russian. doi: 10.20514/2226-67042016-6-3-36-41.

11. Ratnikova LI, Ship SA, Ivankova GI, Mikheeva TV, Misyukevich ND. Differential eygnostic diagnostics with diseases of surgical profile. Journal Infectology. 2016;8(2S):80-1. Russian.

12. Ramchandani M, Kong M, Tronstein E, Selke S, Mikhaylova A, Magaret A, et al. Herpes Simplex Virus Type 1 Shedding in Tears and Nasal and Oral Mucosa of Healthy Adults. Sex Transm Dis. 2016 Dec;43(12):756-60. doi: 10.1097/OLQ.0000000000000522. PMID: 27835628; PMCID: PMC5117635.

13. Johnston C, Corey L. Current Concepts for Genital Herpes Simplex Virus Infection: Diagnostics and Pathogenesis of Genital Tract Shedding. Clin Microbiol Rev. 2016 Jan;29(1):149-61. doi: 10.1128/ CMR.00043-15. PMID: 26561565; PMCID: PMC4771215.

Received: 04.01.2021 